\title{
Implementasi Fungsi dan Manajemen Kehumasan Direktorat Pengelolaan Media Publik Kementerian Komunikasi dan Informatika dalam Sosialisasi UU KIP
}

\author{
Intan Tanjung Sari \\ Mahasiswi Pasca Sarjana Manajemen Komunikasi \\ FISIP Universitas Indonesia (UI), Jakarta \\ Iwan Awaluddin Yusuf \\ Dosen Program Studi Ilmu Komunikasi \\ Universitas Islam Indonesia (UII), Yogyakarta
}

\begin{abstract}
The purpose of this study is to determine the implementation of functions and management of public relations (PR) performed by Directorate of Media, Ministry of Communications and Information Technology in the socialization of the acts about Public Information. This study also determines the method and the factors that support as well as hinder the socialization. Based on this study, Directorate of Media has conducted functions and management of $P R$ to socialize the Freedom of Information Law. PR functions used in this study is publicity through the media, writing activity with a theme related news format Freedom of Information Law, website development and web interface, media relations to expand the reach of socialization, and $P R$ function as communication techinician. $P R$ Management related to socialization through stages fact finding, planning the socialization mechanisms, action and communication or the realization the plan, and evaluation.
\end{abstract}

Keywords: functions implementation and public relation management, socialization of Freedom of Information Law, Directorate of Media Ministry of Communications and Information Technology

\begin{abstract}
Abstrak
Kajian ini bertujuan untuk melihat implementasi dari fungsi dan manajemen Humas yang dilakukan oleh Direktorat Media, Kementerian Komunikasi dan Teknologi Informasi dalam kegiatan sosialisasi Undang-Undang Keterbukaan Informasi Publik (UU KIP). Kajian ini juga menentukan metode yang digunakan serta faktor-faktor pendukung maupu penghambat dalam kegiatan sosialisasi tersebut. Hasil temuan kajian ini menunjukkan bahwa Direktorat Media telah melaksanakan fungsi dan manajemen Humas dalam sosialisasi UU KIP. Fungsi Humas yang digunakan adalah publikasi melalui media, penulisan kegiatan yang berkaitan dengan UU KIP, melakukan website development dan web interface, melakukan media relations untuk melebarkan cakupan sosialisasi, serta fungsi Humas sebagai teknisi komunikasi. Manajemen PR yang berkaitan dengan sosialisasi adalah dengan melakukan fact finding, perencanaan mekanisme sosialisasi, aksi dan komunikasi atau realisasi dari rencana, dan evaluasi.
\end{abstract}

Kata Kunci: implementasi fungsi dan manajemen Humas, sosialisasi UU KIP, Direktorat Media Kementerian Komunikasi dan Teknologi Informasi 


\section{Pendahuluan}

Keterbukaan Informasi Publik merupakan salah satu unsur penting dalam penyelenggaraan pemerintahan yang bersih, transparan dan akuntabel. Dengan adanya Undang Undang No.14 Tahun 2008 tentang Keterbukaan Informasi Publik (UU KIP), hak warga negara Indonesia dalam memperoleh informasi telah dijamin. Keterbukaan informasi suatu lembaga pada publiknya akan meminimalisir kecurigaan atau sikap apriori.

Berdasarkan UU KIP, setiap Badan Publik wajib memberikan informasi secara terbuka kepada masyarakat. Badan Publik yaitu lembaga eksekutif, legislatif, yudikatif, dan badan lain yang fungsi dan tugas pokoknya berkaitan dengan penyelenggaraan negara. Badan Publik juga dapat merupakan organisasi non pemerintah sepanjang sebagian atau seluruh dananya bersumber dari APBN atau APBD, sumbangan masyarakat, dan atau luar negeri. Dengan adanya UU KIP, maka Badan Publik khususnya pemerintah harus menjalankan sosialisasi yang bertujuan memberikan informasi mengenai UU KIP sehingga mudah diterima masyarakat.

Kementerian Komunikasi dan Informatika (Kemenkominfo) sebagai humas pemerintah adalah salah satu Badan Publik yang wajib menjalankan UU KIP. Sosialisasi dan implementasi tentang UU KIP telah dilaksanakan oleh
Kemenkominfo salah satunya melalui Direktorat Pengelolaan Media Publik (Direktorat PMP). Oleh karena itu, tulisan ini membahas implementasi fungsi dan manajemen kehumasan dalam sosialisasi UU No. 14 Tahun 2008 Tentang KIP.

Fungsi dan manajemen Public Relations (PR) dalam melaksanakan sosialisasi sangat penting agar informasi terkait UU KIP tersampaikan dengan efektif. Tulisan ini bertujuan untuk menjawab pertanyaan atau masalah seputar sosialisasi UU KIP oleh Direktorat PMP Kemenkominfo. Maka, tulisan ini akan mendedah bagaimana implementasi fungsi dan manajemen PR yang dijalankan Direktorat PMP dalam sosialisasi UU KIP. Selain itu, tujuan penelitian adalah mengetahui metode yang digunakan dalam sosialisasi, serta mengetahui faktor pendukung dan penghambat pelaksanaan sosialisasi.

\section{Kajian Fungsi dan Manajemen PR}

Beberapa riset mengenai UU KIP pernah dilaksanakan sebelumnya, di antaranya adalah riset yang dilakukan oleh Emmy Poentarie, yang berjudul "Kesiapan Lembaga Publik Negara dalam Implementasi UU No. 14 Tahun 2008. (2010) Poentarie menggunakan metode studi kasus Adopsi Inovasi Internet dalam Penyelenggaraan Layanan Informasi pada Badan Publik Pemerintah Desa Terong, Kecamatan Dlingo, Kabupaten Bantul, Provinsi Daerah Istimewa Yogyakarta. 
Intan Tanjung Sari \& Iwan Awaluddin Yusuf, Implementasi Fungsi dan Manajemen Kehumasan Direktorat Pengelolaan Media Publik Kementerian Komunikasi dan Informatika dalam Sosialisasi UU KIP

Penelitian ini menemukan fakta bahwa Pemerintah Desa Terong menggunakan website sebagai sarana penyampaian informasi mengenai potensi desa kepada masyarakat luas.

Penelitian lain dilakukan oleh Totok Wahyu Abadi, berjudul "Layanan Informasi Publik Berbasis E-Government untuk Meningkatkan Quality Improvement Pelayanan Publik di Jawa Timur" (2010). Penelitian ini memaparkan layanan informasi publik berbasis e-government yang ideal di Jawa Timur. Hasil analisis tentang penyelenggaraan layanan informasi publik oleh instansi pemerintah ada dua model yakni pertama, tatap muka yang menunjukkan citra kurang baik. Faktor yang menyebabkan buruknya layanan informasi publik adalah lemahnya survei masyarakat tentang kebutuhan informasi yang terkait dengan badan publik.

Kedua penelitian tersebut menunjukkan tentang implementasi UU KIP dengan memanfaatkan teknologi internet seperti website dan $e$ government. Dengan demikian, teknologi sangat penting untuk menunjang pelayanan informasi di organisasi pemerintah. Sedangkan salah satu fungsi PR dalam sosialisasi UU KIP oleh Direktorat PMP juga melibatkan teknologi internet berupa website. Fungsi-fungsi Public Relations (PR) menurut Fraser P. Seitel (2004: 10) yang relevan dalam sosialisasi UU KIP antara lain:
1. Menulis (Writing), yakni sebuah keahlian dasar seorang humas dalam menggunakan berbagai sarana yang ada secara tertulis, mulai dari rilis berita sampai pidato, mulai dari brosur hingga iklan yang menjadi cakupan pekerjaannya.

2. Hubungan dengan Media (Media Relations), yakni keahlian dasar seorang humas dalam melakukan hubungan dengan berbagai media (pers) yang ada,dan ini merupakan salah satu fungsi humas "di garis depan."

3. Publisitas (Publicity), yakni keahlian dasar seorang humas dalam melakukan dan menghasilkan publisitas yang positif untuk klien atau perusahaan yang diwakilinya.

4. Pembuatan Web dan Monitoring (Website Development and Web Interface), yakni keahlian dasar seorang humas yang terkait dengan penggunaan dan pemanfaatan media online dalam melakukan interaksi secara interaktif dengan publik perusahaan. Yang terpenting media interaktif yang telah dibuat perusahaan ini juga harus diimbangi dengan kegiatan monitoring respon publik, termasuk memberikan tanggapan langsung terhadap isu-isu atau opini publik yang sedang berkembang terkait dengan perusahaan.

Selain fungsi PR di atas, tulisan ini juga merujuk pada teori peran PR dalam organisasi antara lain (Grunig, 1992: 396): 


\section{Communication Technician}

Tugas yang dikerjakan PR adalah melakukan komunikasi dan keterampilan jurnalistik serta melaksanakan keputusan yang dibuat oleh pimpinan. Ia tidak melakukan pengambilan keputusan dan tidak melakukan penelitian untuk merencanakan dan mengevaluasi pekerjaan mereka.

2. Expert Prescriber

PR berfungsi dan berperan sebagai orang yang ahli melakukan penelitian dan merumuskan-merumuskan masalah organisasi yang berkaitan dengan bidang komunikasi serta gangguan komunikasi dalam pencapaian tujuan organisasi. Selain itu, PR juga mencari upaya solusi permasalahan melalui programprogram yang bermanfaat, dan bertanggung jawab atas pelaksanaan program.

\section{Communication Facilitator}

PR berperan sebagai perantara atau mediator yang peka serta menjaga arus komunikasi dua arah berjalan dengan baik antara organisasi dengan publiknya (sering juga disebut liaison, interpreter/penerjemah, atau sebagai mediator).Peran fasilitator juga mengenali publik di sekeliling organisasi dan membuat keputusan yang berkaitan dengan kebijakan, prosedur serta aktivitas yang diminati oleh kedua belah pihak.

\section{Problem Solving Facilitator}

Fungsi PR adalah menolong organisasi dalam memecahkan persoalan komunikasi yang ada. PR di sini menjadi bagian dari tim perencanaan strategis organisasi. Ia bekerja sama dengan anggota tim lainnya untuk memberikan solusi permasalahan yang ada, mulai dari identifikasi permasalahan, perencanaan, pelaksanaan sampai dengan evaluasi program pemecahan masalah

Dari penelitian sebelumnya, ditemukan fakta bahwa penyampaian informasi publik terhambat karena kurangnya evaluasi. Dalam menjalankan sebuah program diperlukan adanya tahapan manajerial sehingga suatu kegiatan atau program dapat berlangsung sistematis dan efektif. Dalam sosialisasi UU KIP, Direktorat PMP juga menjalankan tahapan proses manajemen kehumasan mulai dari identifikasi masalah hingga evaluasi. Tahapan manajemen PR menurut Cutlip, et.al. (2007: 320-435) adalah sebagai berikut:

1. Fact Finding/Mendefinisikan Problem Langkah pertama ini mencakup penyelidikan dan memantau pengetahuan, opini, sikap, dan perilaku pihak-pihak yang terkait dengan dan dipengaruhi oleh, tindakan dan kebijakan organisasi. Pada dasarnya ini adalah fungsi inteligen organisasi. Fungsi ini menyediakan dasar untuk semua langkah dalam proses pemecahan problem dengan 
Intan Tanjung Sari \& Iwan Awaluddin Yusuf, Implementasi Fungsi dan Manajemen Kehumasan Direktorat Pengelolaan Media Publik Kementerian Komunikasi dan Informatika dalam Sosialisasi UU KIP

menentukan "Apa yang sedang terjadi saat ini?”

\section{Planning/Perencanaan}

Informasi yang dikumpulkan dalam langkah pertama digunakan untuk membuat keputusan tentang program publik, strategi tujuan, tindakan dan komunikasi, taktik dan sasaran. Langkah ini akan mempertimbangkan temuan dari langkah dalam membuat kebijakan dan program organisasi. Langkah kedua ini akan menjawab pertanyaan "Berdasarkan apa kita tahu akan tentang situasi, dan apa yang harus kita lakukan atau apa yang harus kita ubah, dan apa yang harus kita katakan?”

3. Action and Communicating/ Komunikasi

Langkah ketiga adalah mengimplementasikan program aksi dan komunikasi yang didesain untuk mencapai tujuan spesifik untuk masing-masing publik dalam rangka mencapai tujuan program. Pertanyaannya dalam langkah ini adalah "Siapa yang harus melakukan dan menyampaikannya, dan kapan, di mana, dan bagaimana caranya?”

4. Evaluation/Mengevaluasi Program

Langkah terakhir dalam proses ini adalah melakukan penilaian atas persiapan, implementasi, dan hasil dari program. Penyesuaian akan dilakukan sembari program diimplementasikan, dan didasarkan pada evaluasi atas umpan balik tentang bagaimana program itu berhasil atau tidak. Program akan dilanjutkan atau dihentikan setelah menjawab pertanyaan "Bagaimana keadaan kita sekarang atau seberapa baik langkah yang telah kita lakukan?”

\section{Metode Penelitian}

Penelitian ini menggunakan paradigma konstruktivis yang bertujuan merekonstruksi realitas sosial secara dialektis antara peneliti dengan pelaku sosial yang diteliti (Hidayat, 1999: 39-40). Penelitian ini menggunakan pendekatan deskriptif kualitatif. Dalam pendekatan kualitatif, peneliti melakukan wawancara, observasi langsung terhadap objek yang akan diteliti dan penggunaan dokumen resmi. Peneliti menjadi instrumen riset yang harus terjun langsung di lapangan, karena riset ini bersifat subjektif dan hasilnya bukan untuk digeneralisasikan (Kriyantono, 2008: 57). Teknik pengumpulan data dalam penelitian adalah perpaduan antara wawancara dan observasi. Metode analisis yang digunakan adalah teknik reduksi-kategorisasi data yang merangkum, memilah hal-hal pokok, serta memfokuskan pada hal-hal penting yang relevan dengan penelitian.

\section{Hasil dan Pembahasan}

Fungsi PR yang dijalankan Direktorat Pengelolaan Media Publik Kemenkominfo dalam sosialisasi UU KIP terkait dengan publisitas, penulisan materi publikasi, pemanfaatan website, 
dan aktivitas media relations atau hubungan dengan media. Selain menjalankan fungsi PR terkait sosialisasi UU KIP, Direktorat PMP tentunya juga melakukan proses manajemen kegiatan PR seperti fact finding, planning, action and communicating hingga evaluation. Fungsi dan manajemen PR yang dijalankan Direktorat PMP dalam sosialisasi UU KIP akan dibahas satu persatu dalam temuan penelitian yang didapatkan.

\section{a. Analisis Fungsi Public Relations}

1. Publisitas / Publicity

Publisitas merupakan kegiatan utama yang dilakukan Direktorat PMP untuk menginformasikan suatu kebijakan baru pemerintah.Sosialisasi UU KIP melalui aktivitas publikasi bertujuan untuk memasyarakatkan kebijakan baru tersebut kepada Badan Publik dan masyarakat. Dengan adanya sosialisasi, Badan Publik dan masyarakat diharapkan dapat mengetahui, mengerti, dan menjalankan UU KIP. Sebagai salah satu fungsi kehumasan, kegiatan publisitas dapat dilakukan dengan berbagai variasi media seperti media elektronik, media cetak, internet dan media tatap muka. Direktorat PMP mengklasifikasikan penggunaan media publisitas ke dalam tiga jenis media yaitu media online, media cetak serta media audio visual dan luar ruang.

a. Media Online
Media online yang digunakan dalam sosialisasi UU KIP adalah website dengan domain www.infopublik.org serta pemanfaatan jaringan media center milik Direktorat PMP Kemenkominfo, yang ada di seluruh Propinsi di Indonesia. Portal berita www.infopublik.org berisi konten sosialisasi UU KIP yang dilakukan oleh pemerintah pusat maupun daerah.Hal ini disebabkan karena fungsi Government Public Relations Kemenkominfo yang berperan dalam menginformasikan kegiatan di berbagai lembaga pemerintah baik pusat atau daerah terkait sosialisasi dan progres implementasi UU KIP.

b. Media Cetak

Publisitas dalam media cetak sendiri dilakukan melalui Tabloid Komunika dan Jurnal Dialog.Kedua produk cetak ini memiliki jangkauan distribusi yang sangat luas ke seluruh wilayah di Indonesia.

c. Media Audio Visual dan Luar Ruang

Media-media yang dimaksud dalam Media Audio Visual dan Luar Ruang antara lain yaitu Dialog Interaktif di televisi, Pameran (Pekan Informasi Nasional), serta penerbitan beberapa buku yang berkaitan dengan UU KIP.

\section{Menulis/Writing}

Dalam sosialisasi UU KIP, aktivitas menulis yang dilakukan adalah penulisan materi berita untuk keperluan publikasi.Publikasi tulisan tentang 
sosialisasi UU KIP dimuat dalam mediamedia yang digunakan seperti buku, tabloid, jurnal, maupun konten yang ada di dalam portal.Berita yang ditulis menggunakan format feature news dan straight news. Berikut adalah contoh kutipan berita di portal www.infopublik.org mengenai implementasi UU KIP di Samarinda:

Kita lihat Diskominfo Kaltim memberi perhatian sangat serius. Diskominfo ini telah membuat kebijakan yang agak unik dan mengarah pada dukungan pelaksanaan keterbukaan informasi publik," ujar Henry saat memberi sambutan pada peresmian Warung Informasi Etam Kaltim (WIEK) di Dinas Kominfo Kaltim, Samarinda, Rabu (7/11) siang. ${ }^{1}$

3. Pembuatan Web dan Monitoring/ Website Development and Web Interface

Munculnya media baru atau media online yang bersifat interaktif juga dimanfaatkan oleh Direktorat Pengelolaan Media Publik sebagai sarana sosialisasi UU KIP yang utama.Hal ini dibuktikan dengan adanya portal berita www.infopublik.org yang memiliki daya jangkau sangat luas. Informasi yang tedapat pada portal berita tidak hanya informasi di pemerintah pusat saja, melainkan juga di pemerintah daerah yang bekerja sama dengan media center

\footnotetext{
1 "Kaltim Agak Unik, Maju Selangkah Laksanakan KIP,"

http://infopublik.org/mc/kalimantan_timur/index.p hp page $=$ news $\&$ newsid $=35722$, diakses 1

November 2012.
}

daerah. Informasi dalam website ini meliputi sosialisasi UU KIP terutama terkait perkembangan pelaksanaannya. Dengan demikian, masyarakat dapat ikut mengawasi pelaksanaan sosialisasi dan implementasi UU KIP baik di pemerintah pusat maupun daerah.

Berikut adalah contoh berita di website info publik terkait sosialisasi UU KIP:

Subang, InfoPublik - Pada dasarnya UU No. 14 tahun 2008 tentang Keterbukaan Informasi Publik (KIP) mengakomodir UU yang telah ada, yaitu dengan menyebutkan informasi yang kecualikan di antaranya rahasia negara (UU KIP Pasal 6 ayat 3 huruf a), rahasia pribadi (UU KIP Pasal 6 ayat 3 huruf b) dan informasi usaha/bisnis (UU KIP Pasal 6 ayat 3 huruf c). ${ }^{2}$

Pengelolaan website juga perlu dimonitor atau diawasi, sehingga efektivitas penggunaan media ini dalam sosialisasi UU KIP dapat diukur. Monitoring yang dilakukan Direktorat PMP terhadap website sejauh ini adalah merekap jumlah pengunjung website tersebut.

\section{Hubungan Media/Media Relations \\ Direktorat Pengelolaan Media Publik} Kemenkominfo juga melakukan aktivitas media relations dengan media massa lain dalam mensosialisasikan UU KIP. Selain

\footnotetext{
2“Pertemuan Bakohumas di Kabupaten Subang Tentang Keterbukaan Informasi Publik," http://infopublik.org/mc/maluku_utara/index.php?p age $=$ news \&newsid $=34214$ (akses, 1 November 2012)
} 
menggunakan website, jurnal, tabloid dan penerbitan buku, Direktorat PMP Kemenkominfo juga melakukan kerja sama dengan Metro TV dalam sosialisasi UU KIP. Kerja sama yang dilakukan adalah penayangan Dialog Interaktif di Metro TV. Aktivitas media relations dengan Metro TV dilakukan dalam bentuk pembelian slot atau durasi untuk sosialisasi UU KIP dengan tema "Peringatan Hari Hak Untuk Tahu Dalam Mendukung Keterbukaan Informasi Publik."

\section{b. Analisis Peran Public Relations dalam Organisasi}

Direktorat PMP Kemenkominfo memiliki peran sebagai Communication Technician atau Teknisi Komunikasi. Fungsi-fungsi yang dilakukan dalam menjalankan peran ini adalah penulisan atau kegiatan jurnalisitik. Seperti penjelasan hasil penelitian sebelumnya, Direktorat PMP Kemenkominfo menjalankan fungsi yang sangat bersifat teknis seperti publisitas, penulisan materi publikasi dengan format berita baik feature mapun straight news. Fungsi teknis lain yang dilakukan Direktorat PMP dalam sosialisasi UU KIP adalah melakukan aktivitas media relations terkait publisitas tentang sosialisasi UU KIP, serta pembuatan dan monitoring website.

Berdasarkan peran PR dalam organisasi mulai dari Communication Technician, Expert Prescriber,
Communication Facilitator, serta Problem Solving Facilitator, Direktorat PMP hanya menjalankan peran PR sebagai fungsi manajemen pada tataran terendah yaitu Teknisi Komunikasi seperti yang telah dibahas sebelumnya. Peran dalam melakukan penelitian, keterlibatan dalam membuat kebijakan serta pemecahan masalah dilaksanakan oleh seluruh Direktorat yang ada di Direktorat Jenderal Informasi dan Komunikasi Publik (Ditjen IKP) secara terintegrasi.

\section{c. Analisis Manajemen Public Relations}

\section{Fact Finding}

Pelaksanaan sosialisasi UU KIP oleh Direktorat PMP didasarkan pada beberapa alasan. Selain karena sosialisasi merupakan tugas pokok, terdapat pula fakta-fakta atau realitas sosial yang mengharuskan Direktorat PMP dan Badan Publik lain mensosialisasikan UU KIP ini. UU KIP merupakan kebijakan atau peraturan baru untuk meminimalisir praktik korupsi karena ketidaktahuan masyarakat akan pengelolaan pemerintah. Dengan demikian, peraturan baru ini harus disebarluaskan kepada masyarakat, karena masyarakat memiliki hak untuk mengakses informasi tentang penyelenggaraan pemerintah oleh Kemenkominfo.

Direktorat PMP, Kemenkominfo cukup jeli dalam mengidentifikasi permasalahan yang mendasari pentingnya sosialisasi UU KIP. Selain itu, Direktorat 
Intan Tanjung Sari \& Iwan Awaluddin Yusuf, Implementasi Fungsi dan Manajemen Kehumasan Direktorat Pengelolaan Media Publik Kementerian Komunikasi dan Informatika dalam Sosialisasi UU KIP

PMP juga menyadari tantangan pelaksanaan sosialisasi yaitu jumlah Badan Publik yang tidak sedikit, masyarakat yang heterogen dan mindset ketertutupan pemerintah selama ini. Oleh karena itu, praktik manajemen PR dilakukan oleh Direktorat PMP agar perencanaan dan realisasi program sosialisasi dapat berjalan sistematis, efektif, tepat waktu, serta mencapai tujuan.

\section{Planning}

Perencanaan kegiatan sosialisasi dibuat berdasarkan fakta pentingnya sosialisasi UU KIP.Perencanaan pertama yaitu menentukan siapa saja yang menjadi target audiens utama yaitu Badan Publik dan Masyarakat. Perencanaan selanjutnya adalah menetapkan tujuan kegiatan atau target sosialisasi. Sosialisasi dengan target audiens aparatur negara bertujuan untuk memberikan kesadaran agar melaksanakan UU KIP serta mengubah mindset para praktisi pemerintah untuk selalu terbuka dalam memberikan informasi kepada masyarakat. Tujuan sosialisasi dengan target masyarkat hanya sampai pada tahap kesadaran (awareness). Penetapan target audiens dan target kegiatan menjadi dasar pertimbangan pemilihan jenis media yang akan digunakan.

Perencanaan selanjutnya adalah pemilihan jenis media yang digunakan antara lain adalah media online (portal berita), media cetak (Jurnal Dialog dan
Tabloid Komunika), dialog interaktif, pameran dan penerbitan buku khusus. Rencana sosialisasi UU KIP yang selanjutnya adalah melalui event pameran. Salah satu upaya sosialisasi UU KIP adalah Pekan Informasi Nasional 2011 yang kemudian disingkat menjadi PIN 2011. PIN adalah acara khusus berupa pameran yang dianggap efektif untuk mendukung kegiatan Direktorat PMP dalam sosialisasi UU KIP, karena PIN dihadiri oleh seluruh instansi yang berkaitan dengan komunikasi serta dapat pula dihadiri oleh masyarakat umum tanpa dikenakan biaya.

Hal lain yang penting untuk direncanakan adalah mengenai jangka waktu pelaksanaan serta pihak yang bertanggung jawab melaksanakan sosialisasi UU KIP. Sesuai dengan peraturan perundangan, jangka waktu sosialisasi dilaksanakan selama dua tahun sejak UU KIP diundangkan pada tahun 2008. Pelaksanaan kegiatan sosialisasi UU KIP oleh Direktorat PMP, Kemenkominfo dilaksanakan oleh seluruh pejabat dan karyawan yang bersangkutan meliputi Direktur Pengelolaan Media Publik, Kepala Subdit Media Online, Kepala Subdit Media Cetak, Kepala Subdit Media Audio Visual dan Luar Ruang, serta seluruh staf dan karyawan.

\section{Action and Communicating}

Pada tahap ini, Direktorat PMP mulai mengomunikasikan rencanarencana yang telah dibuat sebelumnya 
terkait sosialisasi UU KIP. Berikut langkah komunikasi melalui media-media tersebut:

\section{a. Media Online}

Untuk sosialisasi melalui portal berita, mekanismenya diawali dengan rapat redaksi yang menghadirkan seluruh staf dan pejabat di lingkungan Direktorat PMP. Rapat redaksi membahas tentang agenda setting. Agenda pemberitaan yang dimaksud adalah pemilihan konten terkait UU KIP seperti sosialisasi tentang Pejabat Pengelola Informasi dan Dokumentasi (PPID), sengketa informasi, informasi yang tidak boleh disampaikan dan lainlain. Sosialisasi UU KIP oleh Direktorat PMP dikomunikasikan melalui melalui portal berita dan media center dalam bentuk naskah berita. Mekanisme operasional sosialisasi melalui tulisan berupa berita sesuai dengan aktivitas keredaksian pada media-media yang sudah profesional pada umumnya.

b. Media Cetak

Seperti sosialisasi menggunakan media online, metode sosialisasi melalui media cetak juga menggunakan format berita. Penyusunan konten berita tidak secara tersurat tentang UU KIP, melainkan dikemas dalam suatu tema berita.Mekanisme operasional penerbitan berita tentang UU KIP, sesuai dengan SOP penerbitan media cetak yang sudah ada. Di bawah ini adalah contoh berita mengenai sosialisasi UU KIP yang dimuat dalam
Tabloid Komunika Edisi 23, Desember 2011:

Seiring dengan disahkannya Undang-Undang No. 14 tahun 2008 tentang Keterbukaan Informasi Publik (UU KIP), keterbukaan informasi publik di setiap Badan Publik menjadi keniscayaan yang tidak bisa ditawar-tawar lagi. UU KIP menjamin setiap warga negara untuk mengakses informasi publik di seluruh badan publik di Indonesia, dan badan publik wajib menyediakan informasi tersebut sesuai ketentuan yang diatur dalam UU. 3

c. Media Audio Visual dan Luar Ruang Selanjutnya adalah sosialisasi UU KIP oleh Direktorat PMP yang dikomunikasikan melalui metode dialog interaktif di televisi. Dialog interaktif tersebut berlangsung pada hari Selasa, 4 Oktober 2011 bertempat di Grand Studio Metro TV, Jl. Pilar Mas Raya, Kedoya, Kebun Jeruk Jakarta Barat. Narasumber yang hadir dalam dialog adalah Direktur Jenderal Informasi dan Komunikasi Publik yaitu Freddy H. Tulung. Tahap aksikomunikasi dalam sosialisasi UU KIP, juga dilaksanakan melalui kegiatan pameran.

Pameran yang diselenggarakan oleh Kemenkominfo melalui Direktorat PMP adalah "Pekan Informasi Nasional (PIN) 2011.” Selain dalam rangka sosialisasi UU KIP, pameran tersebut juga

\footnotetext{
3“"Informasi Publik sebuah keniscayaan," Tabloid Komunika, Edisi VII, Desember, 2011, hal. 2.
} 
Intan Tanjung Sari \& Iwan Awaluddin Yusuf, Implementasi Fungsi dan Manajemen Kehumasan Direktorat Pengelolaan Media Publik Kementerian Komunikasi dan Informatika dalam Sosialisasi UU KIP

diselenggarakan dalam rangka memperingati Hari Kebangkitan Nasional serta Hari Pendidikan Nasional.Pameran PIN 2011 dilaksanakan di Surakarta pada tanggal 20-25 Mei 2011. Sebelum menyelenggarakan pameran,

Direktorat PMP bersama Direktorat lain di Kemenkominfo melakukan berbagai persiapan seperti "Rapat Koordinasi Pembahasan Teknis Pelaksanaan Pameran PIN 2011.”

\section{Evaluation}

Dalam pelaksanaan evaluasi, terdapat poin-poin indikator keberhasilan atas pelaksanaan kegiatan yang ditentukan oleh Komisi Informasi (KI) Pusat. Komisi Informasi sebagai badan pengawas implementasi UU KIP menentukan beberapa poin indikator keberhasilan sosialisasi yang dilakukan oleh suatu Badan Publik. Tiga indikator utama keberhasilan sosialisasi UU KIP. Pertama, Badan Publik sebagai target pelaksana UU KIP sudah membentuk Pejabat Pengelola Informasi dan Dokumentasi (PPID). Kedua, berkurangnya sengketa informasi atau bahkan tidak ada sengketa informasi. Ketiga, banyaknya jumlah pemohon informasi ke suatu Badan Publik sehingga menunjukkan partisipasi aktif masyarakat melalui UU KIP.4 Berdasarkan ketiga poin

\footnotetext{
4. Wawancara Dono Prasetyo, Komisioner Bidang Penyelesaian Sengketa Informasi, Komisi Informas Pusat (KIP), Jumat 9 November 2012
}

indikator tersebut, Direktorat PMP dapat dikatakan melakukan sosialisasi UU KIP dengan baik meskipun terhambat beberapa kendala.

\section{d. Analisis SWOT Implementasi Fungsi dan Manajemen PR dalam Sosialisasi UU KIP}

Pada analisis SWOT ini, penulis akan memetakan apa saja yang menjadi faktor pendukung dan penghambat sosialisasi UU KIP oleh Direktorat PMP.

1. Strength/ Kekuatan

Dengan berbagai macam media yang dimiliki oleh Direktorat PMP, maka sosialisasi atau diseminasi informasi tentang UU KIP dapat dilaksanakan dengan frekuensi atau intensitas yang tinggi.Sebagai pemerintah di tingkat pusat atau kementerian, media-media yang dimiliki Direktorat PMP dapat tersebar ke seluruh Indonesia. Hal ini dibuktikan dengan distribusi Tabloid Komunika dan Jurnal Dialog ke berbagai daerah, dan adanya website serta media center yang mampu menjangkau masyarakat banyak.

2. Opportunity/ Peluang

Peluang yang dapat dimanfaatkan Direktorat PMP dalam implementasi fungsi PR terkait sosialisasi UU KIP adalah sistem politik demokrasi yang dianut oleh Indonesia.Dengan adanya demokrasi, maka iklim politik yang dominan saat ini adalah gerakan untuk mendesak adanya reformasi birokrasi di lembaga-lembaga pemerintah.Reformasi 
birokrasi menuntut penyelenggaraan tata kelola pemerintahan yang transparan untuk kepentingan masyarakat dan mengurangi praktik korupsi.

\section{Weakness/ Kelemahan}

Kelemahan yang menjadi faktor penghambat sosialisasi adalah ketiadaan metode pengukuran kinerja atau evaluasi yang masih lemah.Selain itu, kinerja SDM yang kurang optimal sehingga menumbulkan pekerjaan yang "berat sebelah" dan dapat menimbulkan rendahnya tanggung jawab oleh beberapa pegawai. Selain itu, kendala teknis juga menjadi masalah yakni terkait akses portal www.infopublik.org yang masih lambat.

\section{Threat/ Ancaman}

Ancaman yang berasal dari lingkungan eksternal Direktorat PMP dalam sosialisasi UU KIP adalah pemerintah daerah yang kurang dapat bersinergi dengan pemerintah pusat. Ancaman lainnya adalah sikap apriori masyarakat terhadap lembaga pemerintah, sehingga sosialisasi selalu dianggap kurang.

\section{Tabel 1. Analisis SWOT Implementasi Fungsi PR Direktorat PMP dalam Sosialisasi UU KIP}

\section{Strength/ Kekuatan}

a. Variasi media yang beragam dan dikelola sendir seperti Tabloid Komunika, Jurnal Dialog, dan Website.

b. Posisi sebagai lembaga pemerintah pusat yang memiliki jangkauan luas terhadap jaringan media center.

c. Kementerian Komunikasi dan Informatika sebagai inisiator terbentuknya UU KIP.

\section{Weakness/ Kelemahan}

a. Direktorat PMP memiliki peran PR pada tataran terendah, yakni Teknisi Komunikasi sehingga tidak memiliki kapasitas dalam melakukan riset evaluasi terhadap respon publik

b. Evaluasi program yang dilakukan masih lemah

c. Sistem kerja di balik layar yang menghambat interaksi langsung dengan masyarakat terkait pengawasan respon publik terhadap UU KIP

d. Kinerja SDM yang kurang optimal serta tupoksi yang tidak dijalankan dengan maksimal.

e. Permasalahan teknis yang belum bisa ditasi seperti lambatnya jaringan terhadap akses portal.

\section{Opportunity/ Peluang}

a. Sistem pemerintahan demokrasi yang menuntut transparansi pengelolaan pemerintahan oleh lembaga publik,

b. Kemenkominfo memiliki jangkauan publikasi melalui Lembaga Penyiaran Publik

\section{Threat/ Ancaman}

a. kinerja pemerintah daerah yang tidak selaras dengan pemerintah pusat.

b. Sikap apriori atau anggapan buruk masyarakat terhadap pemerintah 
Intan Tanjung Sari \& Iwan Awaluddin Yusuf, Implementasi Fungsi dan Manajemen Kehumasan Direktorat Pengelolaan Media Publik Kementerian Komunikasi dan Informatika dalam Sosialisasi UU KIP

\section{Penutup}

Direktorat PMP Kemenkominfo telah mengimplementasikan fungsi dan manajemen Public Relations (PR) dalam sosialisasi UU KIP. Dalam menjalankan fungsi Kehumasan Pemerintah, Direktorat PMP Kemenkominfo tidak terlepas dari fungsi-fungsi PR umum berdasarkan konsep teori Fraser P. Seitel yang meliputi Publicity, Writing, Website Development and Web Interface, serta Media Relations. Publisitas yang dilakukan terkait UU KIP kepada Badan Publik dan masyarakat melalui berbagai media. Aktivitas menulis atau writing sendiri menggunakan format berita yang berkaitan dengan tema atau topik seputar UU KIP. Pemanfaatan internet berupa website dan aktivitas media relations juga dilakukan dalam sosialisasi UU KIP dengan tujuan memperluas persebaran informasi dengan cepat dan efektif.

Implementasi manajemen PR oleh Direktorat PMP Kemenkominfo dalam sosialisasi UU KIP, dilakukan dengan melalui proses manajerial menurut Cutlip et.al. (2007) yang terdiri dari Fact Finding, Planning, Action and Communicating, dan Evaluations. Definisi masalah dimulai dengan mengidentifikasi urgensi kegiatan sosialisasi UU KIP. Dari masalah tersebut, dilakukan perencanaan terkait mekanisme sosialisasi seperti pemilihan target audiens, penetapan target atau tujuan kegiatan, waktu pelaksanaan, serta media yang digunakan. Selanjutnya, proses komunikasi dimana rencana yang telah disusun mengenai sosialisasi UU KIP mulai direalisasikan dan dioperasionalkan.Tahap terakhir yakni tahap evaluasi keseluruhan pelaksanaan program sosialisasi UU KIP. Metode yang digunakan Direktorat PMP untuk mensosialisasikan UU KIP yang paling utama adalah publisitas dengan memanfaatkan berbagai media

Secara teknis, sosialisasi UU KIP oleh Direktorat PMP dengan melibatkan fungsi-fungsi dan manajemen PR dapat dikatakan berhasil. Namun demikian, Direktorat PMP hanya menjalankan peran sebagai Teknisi Komunikasi yang merupakan tataran terendah peran PR dalam suatu organisasi. Pembuatan kebijakan terkait substansi sosialisasi UU KIP ada pada Ditjen IKP, sehingga peran signifikan Direktorat PMP sendiri hanya sebatas menjalankan tugas secara teknis. Faktor-faktor pendukung sosialisasi UU KIP oleh Direktorat PMP Kemenkominfo adalah adanya variasi media, memiliki jaringan media center daerah, keterlibatan Kemenkominfo sebagai inisiator pembentukan UU KIP. Faktorfaktor yang menjadi penghambat antara lain yaitu evaluasi sosialisasi yang masih lemah, kinerja SDM yang rendah, disintegrasi dengan pemerintah daerah serta sikap apriori atau anggapan buruk masyarakat terhadap pemerintah. 


\section{Daftar Pustaka}

Abadi, Totok Wahyudi. 2010. "Layanan Informasi Publik Berbasis EGovernment untuk Meningkatkan Quality Improvement Pelayanan Publik di Jawa Timur,“ Jurnal Penelitian Ilmu Pengetahuan dan Teknologi Komunikasi, Vol. 12, Juni. hal. 51- 75 .

Cutlip, Scott M., Allen H.Center, Glen M.Broom. 2007. Effective Public Relations. Jakarta: Kencana Prenada Media Group.

Grunig, James E. 1992. Excellence in Public Relations and Communication Management. New Jersey: Lawrence Erlbaum.

Hidayat, Dedy N. 1999. "Paradigma dan Perkembangan Penelitian Komunikasi," Jurnal Ikatan Sarjana Komunikasi Indonesia, No. 3, April. hal. 39-40.

Kriyantono, Rachmat. 2008. Teknik Praktis Riset Komunikasi. Jakarta: Kencana Prenada Media Group.
Poentarie, Emmy. 2010. "Kesiapan Lembaga Publik Negara dalam Implementasi UU No. 14 Tahun 2008," Jurnal Penelitian Ilmu Pengetahuan dan Teknologi Komunikasi, Vol. 12, Juni. hal. 2949.

Seitel, Fraser P. 2004. The Practice of Public Relations. New Jersey: Prentice Hall. . "Kaltim Agak Unik, Maju Selangkah Laksanakan KIP," http://infopublik.org/mc/kalimanta $\mathrm{n} \_$timur/index.php?page $=$news\&ne wsid=35722. Diakses 1 November 2012.

. "Pertemuan Bakohumas di Kabupaten Subang Tentang Keterbukaan Informasi Publik”. http://infopublik.org/mc/maluku_u tara/index.php?page=news\&newsid =34214. Diakses, 1 November 2012.

"Informasi Publik Sebuah Keniscayaan," Tabloid Komunika, Desember, 2011. 